\title{
THE EFFECTS OF MINERAL WOOL FLY ASH ON COHESIVE SOIL STRENGTH BEHAVIOUR
}

\author{
MINDAUGAS ZAKARKA*, ŠARŪNAS SKUODIS, \\ RIMANTAS MACKEVIČIUS, DANUTE் SLIŽYTE் \\ Department of Reinforced Concrete Structures and Geotechnics, \\ Vilnius TECH, Vilnius, Lithuania
}

Received 12 January 2021; accepted 19 May 2021

\begin{abstract}
This research work represents updated results of cohesive soil strength improvement with mineral wool fly ash. In the investigations, these materials were used: Portland cement CEM I 42.5 R, fly ash obtained from a mineral wool production process, sand and clay. Mixtures were prepared as follows: dry mixing of Portland cement and fly ash; dry mixing of sand and clay; adding water into Portland cement and fly ash; adding sand and clay mixture into already prepared Portland cement and fly ash suspension. The content of fly ash replacing Portland cement varied from $0 \%$ to $40 \%$, and the content of sand mixture varied from $20 \%$ to $60 \%$. After 24 hours, investigated samples were taken out from cylinder forms and kept in a desiccator with a humidity of $90 \%$ and at $20{ }^{\circ} \mathrm{C}$ temperature. Uniaxial compressive strength of the samples was determined after 548 days and compared to previous research results obtained after 7, 28 and 183 days. The most predictable compressive strength is for samples, which composition is $100 \%$ cement and $0 \%$ fly ash. In these samples, the highest compressive strength was obtained, comparing them to the other investigated samples. Compressive strength change is minimal for samples with a $10-30 \%$ amount of fly ash. The most significant decrease in compressive strength was obtained for samples with a $40 \%$ fly ash after 183
\end{abstract}

\footnotetext{
* Corresponding author. E-mail:mindaugas.zakarka@vilniustech.lt

Mindaugas ZAKARKA (ORCID ID 0000-0001-7154-126)

Šarūnas SKUODIS (ORCID ID 0000-0001-9467-7255)

Rimantas MACKEVIČIUS (ORCID ID 0000-0002-5643-1147)

Danutė SLIŽYTĖ (ORCID ID 0000-0002-1220-7485)
} 
days. Nonetheless, the compressive strength of these samples increased after 548 days and is almost the same as for samples with 100\% Portland cement.

Keywords: clay, fly ash, sand, soil, stiffness improvement, Portland cement, subgrade stabilisation.

\section{Introduction}

Soil stabilisation is widely used in many road construction applications. There is a possibility to apply such methods for soil stabilisation, which allow to reduce the costs of soil stabilisation and solve ecological problems. Some methods, like stabilisation using recycled asphalt (Zarins, 2020), lime (Firoozi et al., 2017) or slag (Mahedi et al., 2018), have become traditional and are often used. Other methods, like stabilisation using glass waste (Baldovino et al., 2021), shredded tire (Behnood, 2018), volcanic ash (Ghadir \& Ranjbar, 2018), fly ash (Jalal et al., 2020; Riekstins et al., 2020), or ferric chloride solution as electronic industry waste for hardening of polymer resins by soil grouting (Mackevičius et al., 2019) are still being tested, and their applicability is relatively narrow.

Fly ash (FA) has been used successfully in many projects as a low cost and environmentally friendly filler and its effect on the properties of mixed asphalt (Mirković et al., 2019; Woszuk et al., 2019). Fly ash also improves strength characteristics of soils, stabilises bases or subgrades, stabilises backfill, reduces lateral earth pressures, and stabilises embankments to improve slope stability. Fly ash is also used as an expansive soil stabiliser (Jalal et al., 2020; Sharman \& Sivapullaiah, 2016), curing agent for man-made contaminated soil (Li et al., 2018), organic soil stabiliser (Nath et al., 2017), cohesive or non-cohesive soil stabiliser (Binal, 2016; Simatupang et al., 2020; Zakarka et al., 2019), or for other purposes (Elahi et al., 2020; Khajeh et al. 2020; Luo et al., 2018; Phummiphan et al., 2016).

It is well known that the fly ash utilisation problem is complicated because fly ash accounts for $15 \%$ of total ash (Pundinaitè-Barsteigienè et al., 2017). Also, the chemical composition of fly ash varies (Bhatt et al., 2019; Kang et al., 2020) and depends on industry type and provided products (Cho et al., 2019). Fly ash collected during the production of mineral wool gain an advantage due to its constant and more predictable composition (Zakarka et al., 2019). Diversity of the chemical composition of fly ash allows studying the possibilities for reusing local fly ash and makes it possible to achieve different soil strengths and increments of stiffness (Deepak et al., 2020). Due to this reason, fly ash reuse has to be evaluated on a case-by-case basis, as there are many locally unique
Mindaugas Zakarka,

The Effects of Mineral Wool Fly Ash 
THE BALTIC JOURNAL

OF ROAD

AND BRIDGE

ENGINEERING

2021/16(4)

factors like transportation costs, recycling costs, landfill charges, labour costs, and environmental costs (Stonys et al., 2016; Vaitkus et al., 2018). Nevertheless, many countries have promoted the reuse of fly ash waste in sustainable construction (Amran et al., 2021). Also, it is essential to understand the behaviour dependence on the lifetime of construction of soil stabilised with fly ash (Karim et al., 2020). Most often, compression tests of the soil stabilised with fly ash are performed after 2-7 days (Graytee et al., 2018), or after 1-2 weeks (Liang et al., 2020), or after up to 1-2 months (Gu \& Chen, 2020; Liang et al., 2020). There is little information in the literature on the results of the tests of stabilised soil after 2-6 months (Chousidis et al., 2016; Jia et al., 2020; Wong, 2015; Yoobanpot et al., 2017; Zakarka et al., 2019) or even after 1-2 years (Giergiczny, 2019; Moon et al., 2016).

This research represents fly ash as a stabiliser for cohesive soil with the results after 1.5 years compared to previous research (Zakarka et al., 2019) after 7-183 days. Obtained results allow gaining understanding about strength increment of stabilised clay with fly ash in 1.5 years. The sufficient strength after soil strengthening is achieved when the compressive strength reaches more than 0.5 MPa (State Enterprise Lithuanian..., 2012). Conforming to the first testing plan, the investigations were organised after one year, but the COVID-19 pandemic (Župerkienė et al., 2021) was delayed, and results were presented only after 1.5 years. Also, this research provides a possibility to reduce the amount of mineral wool waste because 2.5 million tons of mineral wool waste is generated annually in the European Union, which is one of the most unutilised materials (Yliniemi et al., 2020).

\section{Experimental setup}

Samples were prepared by mixing these materials:

- Portland cement (C) CEM I 42.5 R, which complies with the LST EN 197-1:2011/P:2013 Cement - Part 1: Composition, specifications and conformity criteria for common cements;

- fly ash (FA) obtained from a mineral wool factory in Vilnius (Lithuania) as mineral wool production waste, the chemical composition of which is presented in Table 1;

- sand, which granulometric composition is presented in Figure 1, was also used in previous research (Zakarka et al., 2019);

- clay powder (CP), which chemical composition is presented in Table 1, and water.

The granulometric composition of sand was determined in consonance to LST CEN ISO/TS 17892-4:2017 Geotechnical investigation 
and testing - Laboratory testing of soil - Part 4: Determination of particle size distribution and LST CEN ISO/TS 17892-12:2018 Geotechnical investigation and testing - Laboratory testing of soil - Part 12: Determination of liquid and plastic limits. Investigated sand coefficient of uniformity $C_{u}=2.77$ and coefficient of curvature $C_{c}=0.90$. Conforming to the Lithuanian Geology Survey (2019), investigated sand is assigned to uniform sand (SaU). For investigated sand and clay mixtures, plastic $\left(W_{p}\right)$ and liquid $\left(W_{L}\right)$ limits were determined without fly ash additives, as Trivedi et al. (2013) recommended. When $80 \% \mathrm{CP}$ and $20 \%$ SaU are mixed, $W_{p}=15.1 \%$ and $W_{L}=28.4 \%$. After mixing $60 \% \mathrm{CP}$ and $40 \%$ SaU, $W_{p}=11.6 \%$ and $W_{L}=20.1 \%$, after mixing $40 \% \mathrm{CP}$ and $60 \% \mathrm{SaU}$, $W_{p}=9.3 \%$ and $W_{L}=16.3 \%$. As stated in Engineering Geological and Geotechnical Soil Investigations Classification (Lithuanian Geology Survey, 2019), all sand and clay mixtures are assigned to sandy low plasticity clay (saCIL). Depending on the calcium oxide ( $\mathrm{CaO}$ ) content, fly ash is divided into class C and F (Guo et al., 2017; Kim et al., 2003), which have different effects on mixtures. Fly ash is assigned to class $\mathrm{C}$ if $\mathrm{CaO} 15-35 \%$ or $\mathrm{SiO}_{2}+\mathrm{Al}_{2} \mathrm{O}_{3}+\mathrm{Fe}_{2} \mathrm{O}_{3} \geq 50 \%$ and assigned to class $\mathrm{F}$ if $\mathrm{CaO} \sim 5 \%$ or $\mathrm{SiO}_{2}+\mathrm{Al}_{2} \mathrm{O}_{3}+\mathrm{Fe}_{2} \mathrm{O}_{3} \geq 70 \%$. Investigated mineral wool fly ash assignment to the class $\mathrm{C}$ or $\mathrm{F}$ is complicated because the amount of $\mathrm{SiO}_{2}+\mathrm{Al}_{2} \mathrm{O}_{3}+\mathrm{Fe}_{2} \mathrm{O}_{3}$ is $49.65 \%$ (could be assigned to class $\mathrm{C}$ ), and $\mathrm{CaO}$ amount is $3.52 \%$ (could be assigned to class $\mathrm{F}$ ).

Table 1. Chemical composition of investigated fly ash and clay *

\begin{tabular}{lccc}
\hline \multirow{2}{*}{ Chemical composition } & \multicolumn{2}{c}{ Investigated } \\
\cline { 3 - 4 } & & Fly ash & Clay \\
\cline { 3 - 4 } Silicon dioxide & $\mathrm{SiO}_{2}$ & $40.60 \%$ & Zakarka et al. (2019) \\
Aluminium oxide & $\mathrm{Al}_{2} \mathrm{O}_{3}$ & $2.14 \%$ & $15.7 \%-17.7 \%$ \\
Iron (III) oxide & $\mathrm{Fe}_{2} \mathrm{O}_{3}$ & $6.91 \%$ & $6.1 \%-7.9 \%$ \\
Calcium oxide & $\mathrm{CaO}$ & - & $0.3 \%-1.8 \%$ \\
Magnesium oxide & $\mathrm{MgO}$ & $11.10 \%$ & $2.2 \%-3.2 \%$ \\
Manganese (II) oxide & $\mathrm{MnO}$ & - & $0.1 \%-0.2 \%$ \\
Sodium oxide & $\mathrm{Na}_{2} \mathrm{O}$ & $6.71 \%$ & $0.1 \%-0.3 \%$ \\
Potassium oxide & $\mathrm{K}_{2} \mathrm{O}$ & $6.34 \%$ & $2.9 \%-3.5 \%$ \\
Titanium dioxide & $\mathrm{TiO}_{2}$ & $0.23 \%$ & $0.7 \%-0.9 \%$ \\
Sulfur trioxide & $\mathrm{SO}_{3}$ & $2.41 \%$ & - \\
Phosphorus pentoxide & $\mathrm{P}_{2} \mathrm{O}_{5}$ & - & $0.1 \%-0.2 \%$ \\
Chlorine & $\mathrm{Cl}$ & $4.58 \%$ & - \\
& $\mathrm{Other}$ & $4.67 \%$ & - \\
\hline
\end{tabular}

Note: *by Zakarka et al. (2019).
The Effects of Mineral

Wool Fly Ash

on Cohesive Soil

Strength Behaviour 
To each different composition of the mixture, three sets of cylinder samples were prepared, the diameter of which $4.5 \mathrm{~cm}$, height $-7.0 \mathrm{~cm}$. In total, 15 different compositions were investigated, which are presented in Table 2. Mixtures were made as follows (Figure 2):

1) dry mixing of Portland cement and fly ash;

2) dry mixing of sand and clay;

3) adding water into Portland cement and fly ash;

4) adding sand and clay mixture into already prepared Portland cement and fly ash suspension.

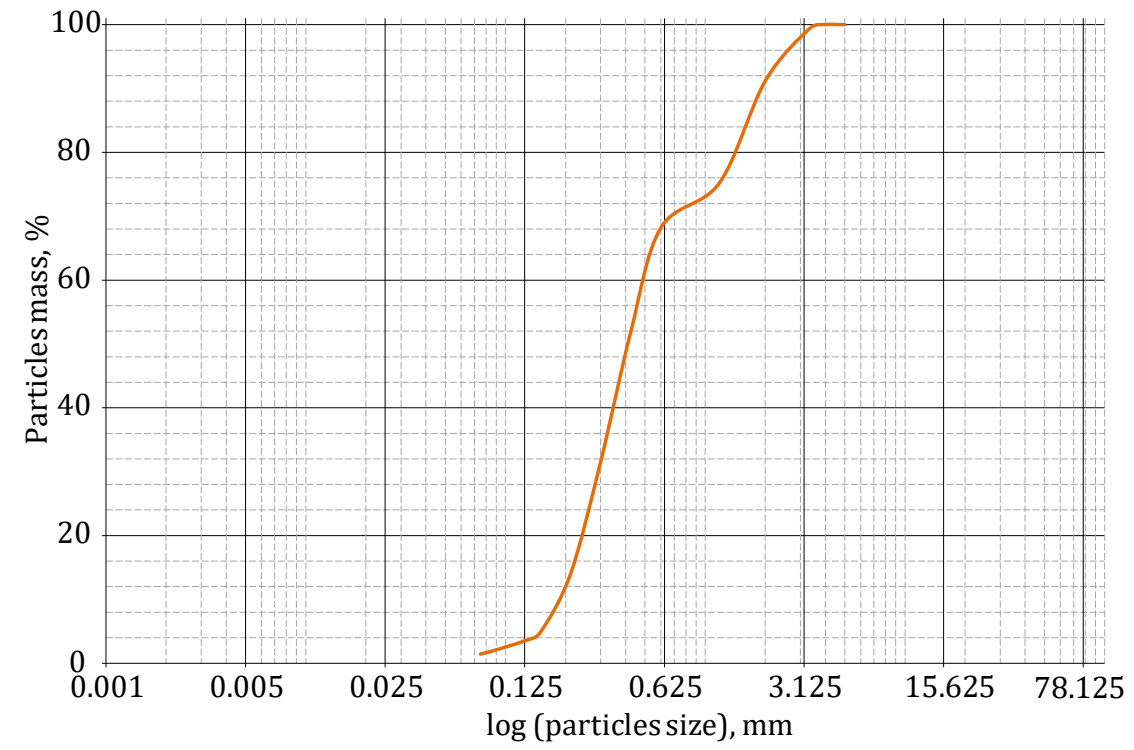

Figure 1. Granulometric composition of investigated sand

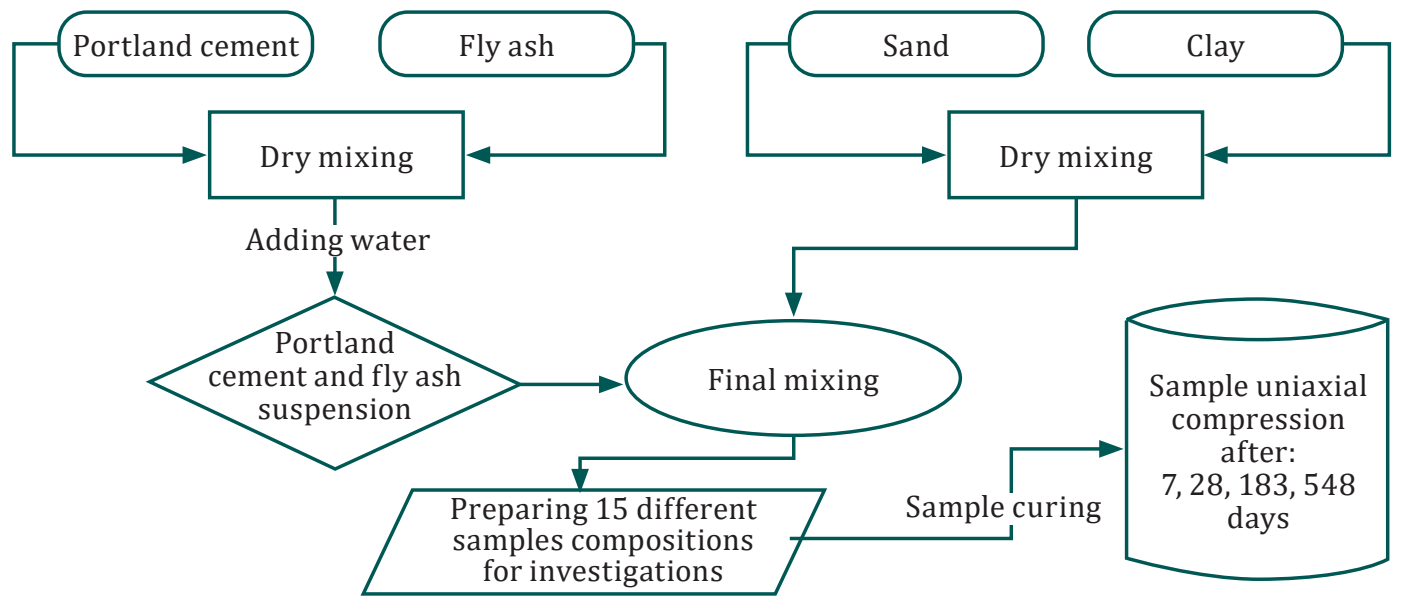

Figure 2. Flowchart of a research program 
It was observed that increasing the water ratio to 1.5 to achieve The Effects of Mineral Wool Fly Ash proper mixing quality for some samples (Table 2). Such an increase in water ratio made it possible to achieve the maximum compressive strength of the prepared sample (Fuller et al., 2018).

Table 2. Composition of samples

\begin{tabular}{|c|c|c|c|c|c|c|}
\hline \multirow{2}{*}{$\begin{array}{l}\text { Sample } \\
\text { No. }\end{array}$} & \multicolumn{2}{|c|}{ Quantity, \% } & \multirow{2}{*}{$\frac{\text { Water }}{\text { Portland cement + fly ash }}$} & \multirow{2}{*}{$\begin{array}{l}\text { Suspension view } \\
\text { before adding } \\
\text { clay and sand }\end{array}$} & \multicolumn{2}{|c|}{ Quantity, \% } \\
\hline & $\begin{array}{c}\text { Portland } \\
\text { cement }\end{array}$ & fly ash & & & clay & sand \\
\hline 1 & \multirow[t]{3}{*}{100.0} & \multirow[t]{3}{*}{0.0} & \multirow[t]{3}{*}{1.0} & & 80.0 & 20.0 \\
\hline 2 & & & & & 60.0 & 40.0 \\
\hline 3 & & & & & 40.0 & 60.0 \\
\hline 4 & \multirow[t]{3}{*}{90.0} & \multirow[t]{3}{*}{10.0} & \multirow[t]{3}{*}{1.0} & & 80.0 & 20.0 \\
\hline 5 & & & & & 60.0 & 40.0 \\
\hline 6 & & & & & 40.0 & 60.0 \\
\hline 7 & \multirow[t]{3}{*}{80.0} & \multirow[t]{3}{*}{20.0} & \multirow[t]{3}{*}{1.0} & & 80.0 & 20.0 \\
\hline 8 & & & & & 60.0 & 40.0 \\
\hline 9 & & & & & 40.0 & 60.0 \\
\hline 10 & \multirow[t]{3}{*}{70.0} & \multirow[t]{3}{*}{30.0} & \multirow[t]{3}{*}{1.0} & & 80.0 & 20.0 \\
\hline 11 & & & & & 60.0 & 40.0 \\
\hline 12 & & & & & 40.0 & 60.0 \\
\hline 13 & \multirow[t]{3}{*}{60.0} & \multirow[t]{3}{*}{40.0} & \multirow[t]{3}{*}{1.5} & & 80.0 & 20.0 \\
\hline 14 & & & & & 60.0 & 40.0 \\
\hline 15 & & & & & 40.0 & 60.0 \\
\hline
\end{tabular}


All investigated samples after 24 hours were taken out from cylinder forms (the diameter of which $4.5 \mathrm{~cm}$, height $-7.0 \mathrm{~cm}$ ) and kept in desiccators with a constant humidity of $90 \%$ and a temperature of $20{ }^{\circ} \mathrm{C}$. The compressive strength of the samples was determined with a $100 \mathrm{kN}$ electromechanical universal testing machine (Walter+Bai AG) after 548 days and compared to previous research (Zakarka et al., 2019) results obtained after 7, 28, and 183 days. The samples were loaded with the sanded surfaces contacting the testing machine platens. The top-loading plate has a spherical hinge. Uniaxial compression ramp $2 \mathrm{~mm} / \mathrm{min}$ was applied. Before determining the uniaxial compressive strength, the density of samples was identified (Figure 3).

The lowest density $\left(1.388 \mathrm{~g} / \mathrm{cm}^{3}\right)$ was obtained for samples of $60 \%$ Portland cement and $40 \%$ fly ash with $80 \%$ clay powder and $20 \%$ sand. The highest density $\left(1.884 \mathrm{~g} / \mathrm{cm}^{3}\right)$ was obtained for samples consisting of $100 \%$ Portland cement and $0 \%$ fly ash with $40 \%$ clay powder and $60 \%$ sand. Sample density tends to increase when the amount of clay is decreased for the same amount of fly ash, and the amount of sand increases. Also, it was noticed that density depends on fly ash amount because fly ash additives decrease total sample density.

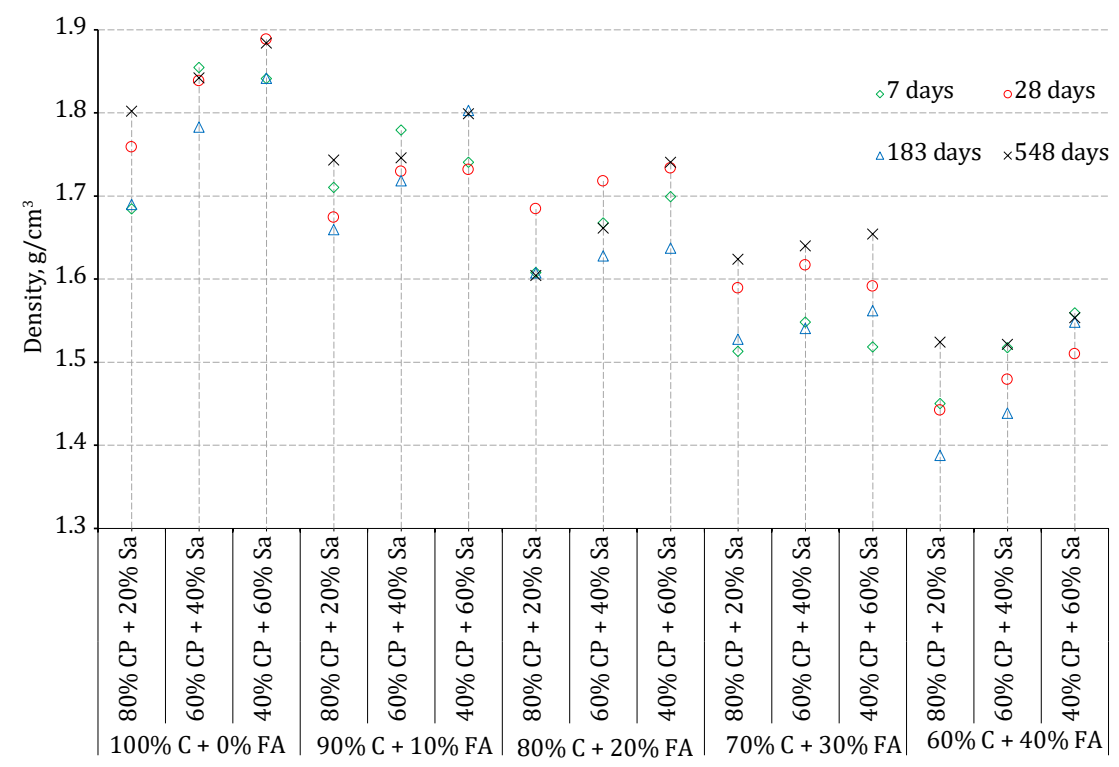

Figure 3. The density of investigated samples 


\section{Analysis of obtained results}

The compressive strength of investigated samples conforming to their composition is presented in Table 3, including previous Zakarka et al. (2019) research results after 7, 28, and 183 days (sample number in Table 3 corresponds to Table 2). Table 3 represent a view of the samples after compression. It was observed that while increasing the amount of fly ash, the quality of the mixture becomes worse. Due to the increased amount of fly ash, the Portland cement conglomerates of poorly mixed samples appear. The size and the amount of conglomerates depend on fly ash amount. Nevertheless, after 1.5 years (548 days), each of the investigated samples reached more than $0.50 \mathrm{MPa}$ compressive strength, which is assumed as sufficient strength after soil strengthening (State Enterprise Lithuanian..., 2012).

Based on the sample failure plane, fly ash concentrations were obtained. When the fly ash in the suspension was increased, larger size and gaps among fly ash concentrations were observed (Table 3). For No. 13-15 samples (Table 3) with 60\% Portland cement and 40\% fly ash total concentration of $70-90 \%$ fly ash in the failure plane was obtained.

Fly ash amount in the suspension proportion was analysed separately versus compressive strength. The results for different compression tests periods are presented in Figures 4-7. Results presented in Figures 4-6 are compiled conforming to Zakarka et al. (2019). Also, such presentation of results makes it possible to analyse the influence of fly ash amount on the compressive strength based on different clay and sand proportions.
Danutė Sližytė

The Effects of Mineral Wool Fly Ash on Cohesive Soil Strength Behaviour 
Table 3. Updated compressive strength of investigated samples after*

\begin{tabular}{|c|c|c|c|c|c|}
\hline \multirow{2}{*}{$\begin{array}{c}\text { Sample } \\
\text { No. }\end{array}$} & \multicolumn{4}{|c|}{ Compressive strength, $\mathrm{MPa}$} & \multirow{2}{*}{$\begin{array}{c}\text { Representative view } \\
\text { of sample } \\
\text { after compression }\end{array}$} \\
\hline & 7 days & 28 days & 183 days & 548 days & \\
\hline 1 & 2.80 & 2.46 & 3.83 & 5.17 & \\
\hline 2 & 3.38 & 3.21 & 5.13 & 4.29 & \\
\hline 3 & 4.19 & 5.64 & 6.85 & 5.16 & \\
\hline 4 & 2.48 & 1.42 & 2.97 & 4.34 & \\
\hline 5 & 2.56 & 3.67 & 3.47 & 5.62 & \\
\hline 6 & 3.52 & 3.34 & 3.52 & 5.46 & \\
\hline 7 & 2.88 & 3.32 & 2.99 & 3.63 & \\
\hline 8 & 3.95 & 2.52 & 3.57 & 5.06 & \\
\hline 9 & 3.74 & 3.25 & 4.18 & 5.10 & \\
\hline 10 & 2.09 & 2.10 & 2.39 & 3.84 & \\
\hline 11 & 3.89 & 2.34 & 2.90 & 3.77 & \\
\hline 12 & 2.07 & 2.01 & 4.46 & 5.54 & \\
\hline 13 & 1.39 & 1.36 & 2.10 & 3.28 & \\
\hline 14 & 1.89 & 1.86 & 1.95 & 5.12 & \\
\hline 15 & 2.35 & 1.47 & 2.59 & 5.26 & \\
\hline
\end{tabular}

Note: * Zakarka et al. (2019). 
Mindaugas Zakarka,

Šarūnas Skuodis,

Rimantas Mackevičius,

Danutè Sližytè

The Effects of Mineral

Wool Fly Ash

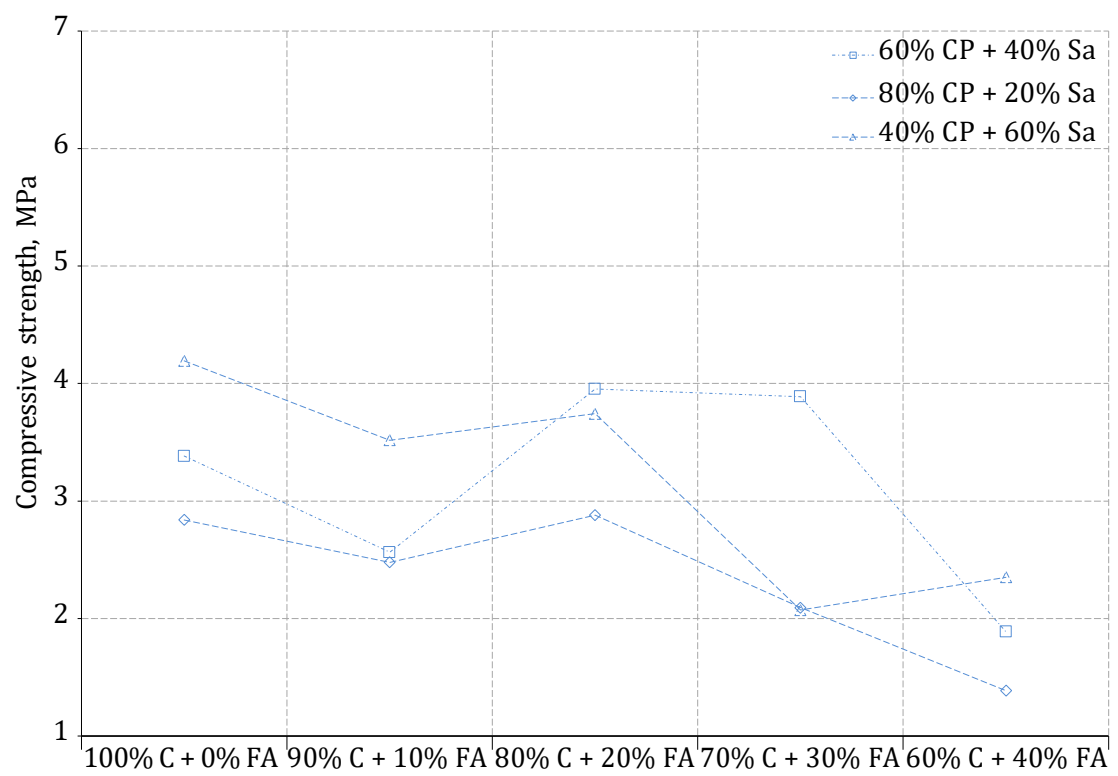

on Cohesive Soil

Strength Behaviour

Figure 4. Fly ash effect on strength after 7 days (Zakarka et al., 2019)

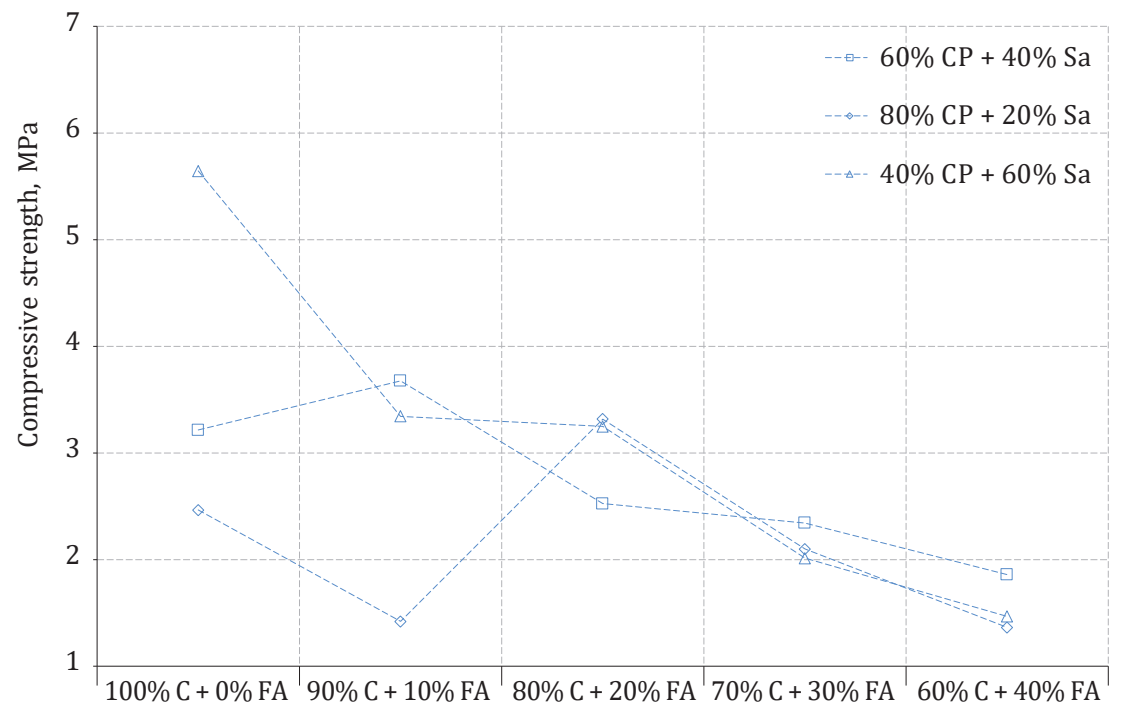

Figure 5. Fly ash effect on strength after 28 days (Zakarka et al., 2019) 


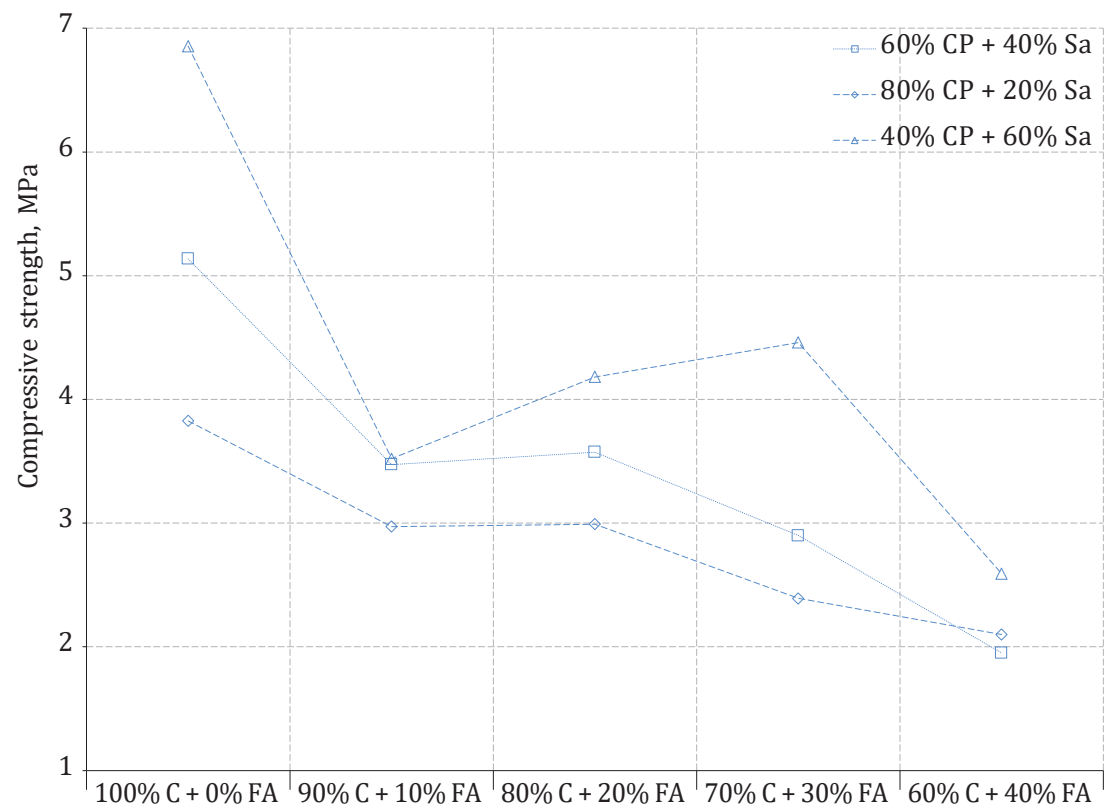

Figure 6. Fly ash effect on strength after 183 days (Zakarka et al., 2019)

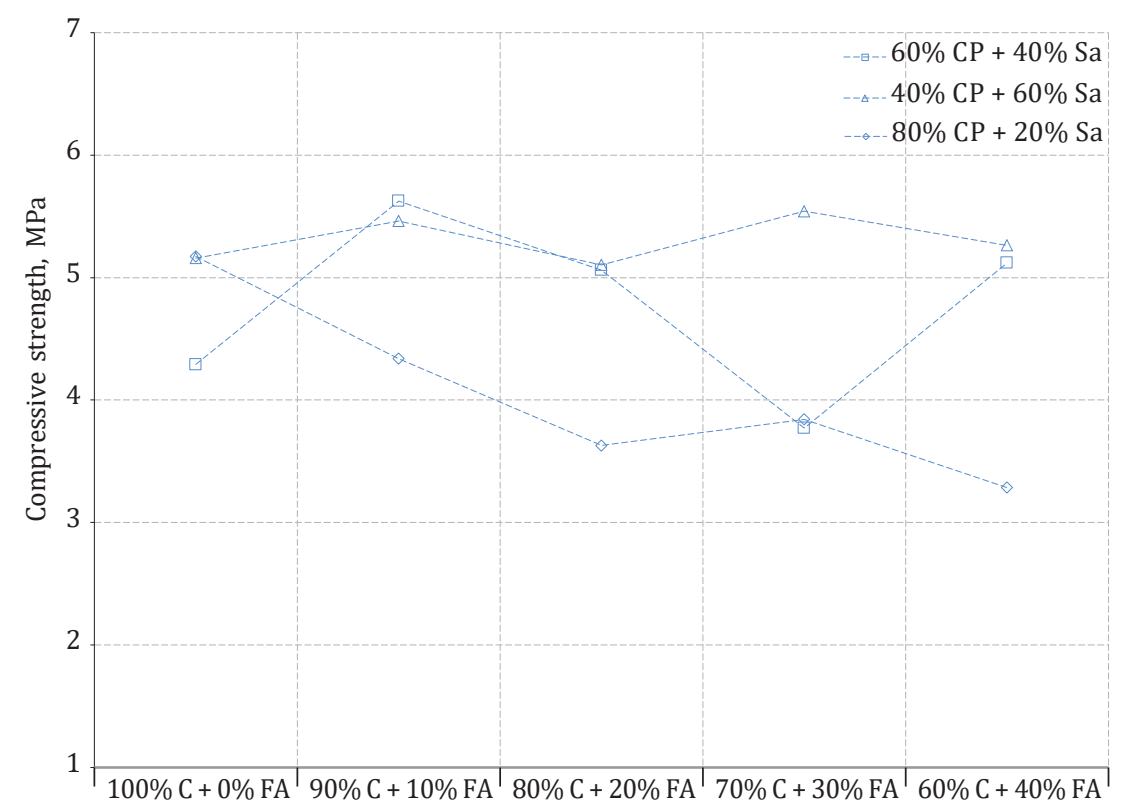

Figure 7. Fly ash effect on strength after 548 days 
Mindaugas Zakarka,

Šarūnas Skuodis,

Rimantas Mackevičius,

Danutè Sližytè

The Effects of Mineral

Wool Fly Ash

on Cohesive Soil

Strength Behaviour compressive strength decreases. The amount of clay in the sample has a significant influence on the compressive strength. The test data approve this fact for compressive strength without fly ash.

After 548 days (Figure 7), for samples composed primarily of sand ( $40 \%$ clay and $60 \%$ sand), the amount of fly ash does not influence compressive strength. For these samples, the average compressive strength obtained is more than $5.0 \mathrm{MPa}$. Samples mainly composed of clay ( $80 \%$ clay and $20 \%$ sand) tend to decrease in compressive strength as the amount of fly ash in the sample increases. For these samples, the obtained compressive strength decreases from 5.0 MPa to 3.0 MPa.

Compressive strength obtained from previous research of Zakarka et al. (2019) after 7-183 days showed that compressive strength decreases if fly ash increases. Analysing compressive strength results after 548 days, fly ash amount has an uncertain influence on the compressive strength, except for samples made with $80 \%$ clay and $20 \%$ sand. A more significant influence on compressive strength was noticed when sand was added to the samples compared to fly ash. In samples without fly ash (here, Portland cement content is 100\%), the compressive strength increased by $77 \%$ from day $28^{\text {th }}$ to day $548^{\text {th }}$. When samples are with maximum fly ash amount (40\%) and minimum Portland cement amount (60\%), the compressive strength increases by $34 \%$ (Figures $8-12$ ).

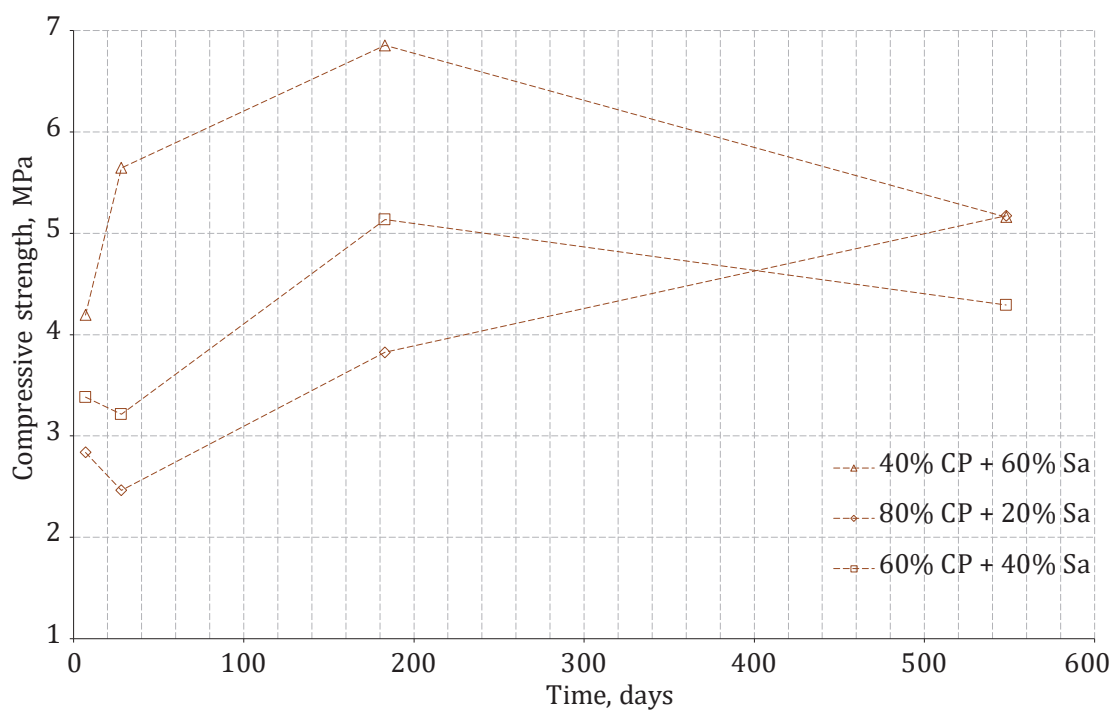

Figure 8. Updated compressive strength of samples (100\% Portland cement + 0\% fly ash) after Zakarka et al. (2019) 


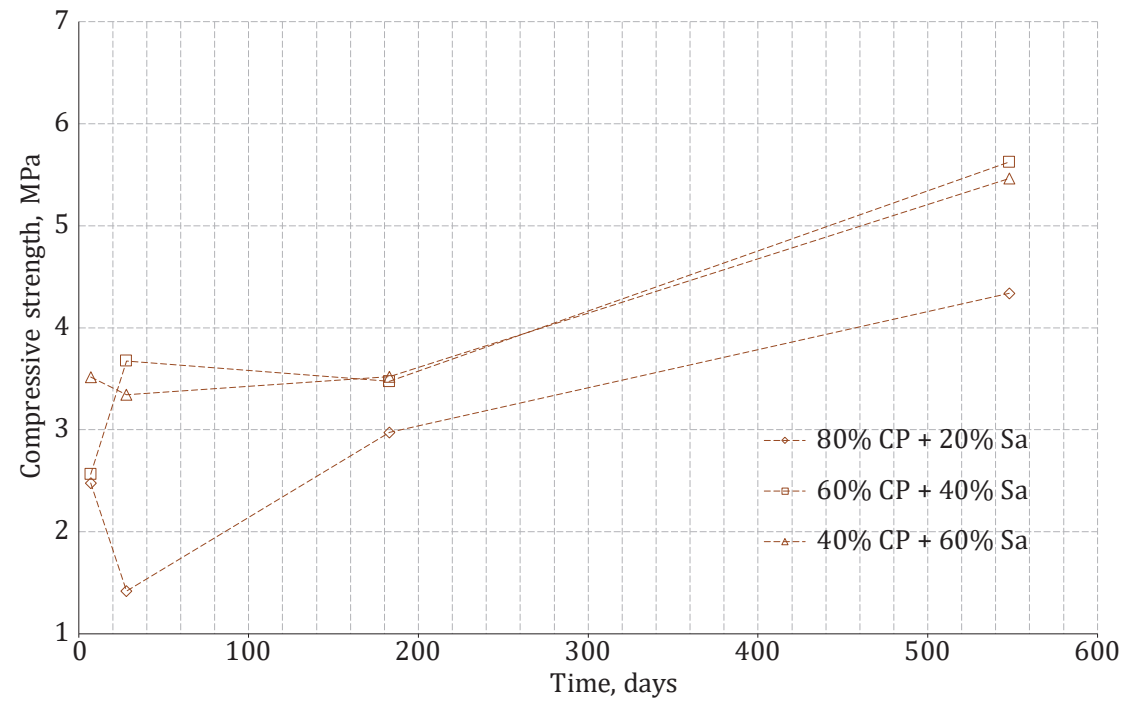

Figure 9. Updated compressive strength of samples (90\% Portland cement $+10 \%$ fly ash) after Zakarka et al. (2019)

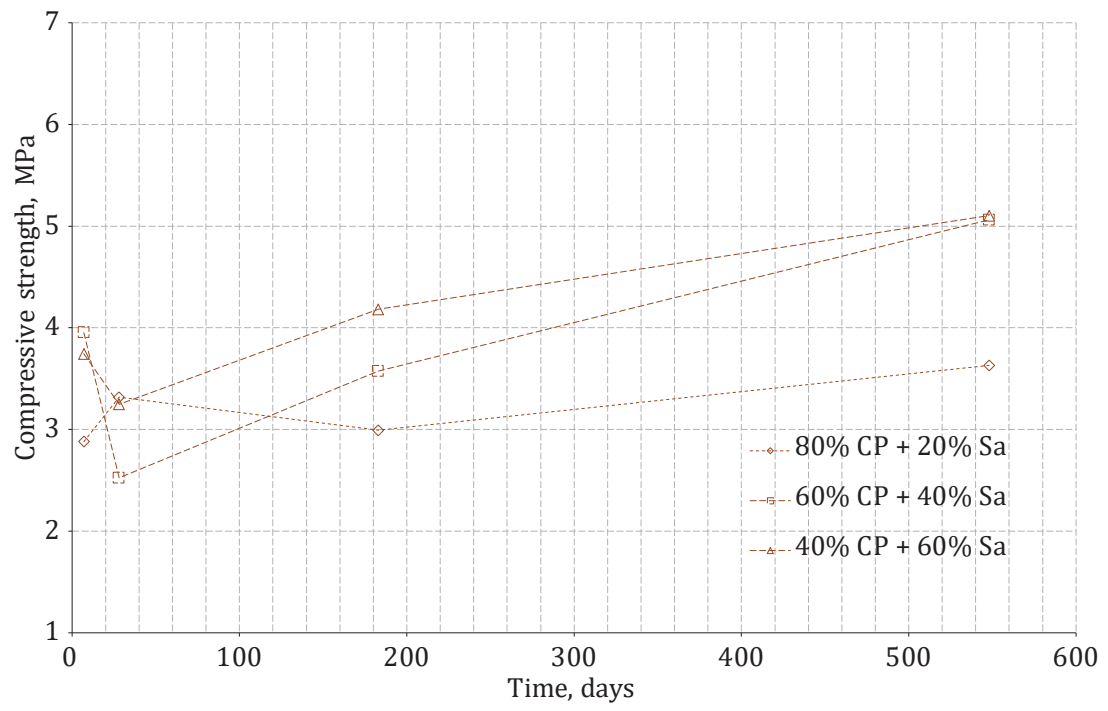

Figure 10. Updated compressive strength of samples (80\% Portland cement $+20 \%$ fly ash) after Zakarka et al. (2019) 
Mindaugas Zakarka,

Šarūnas Skuodis,

Rimantas Mackevičius,

Danutè Sližytè

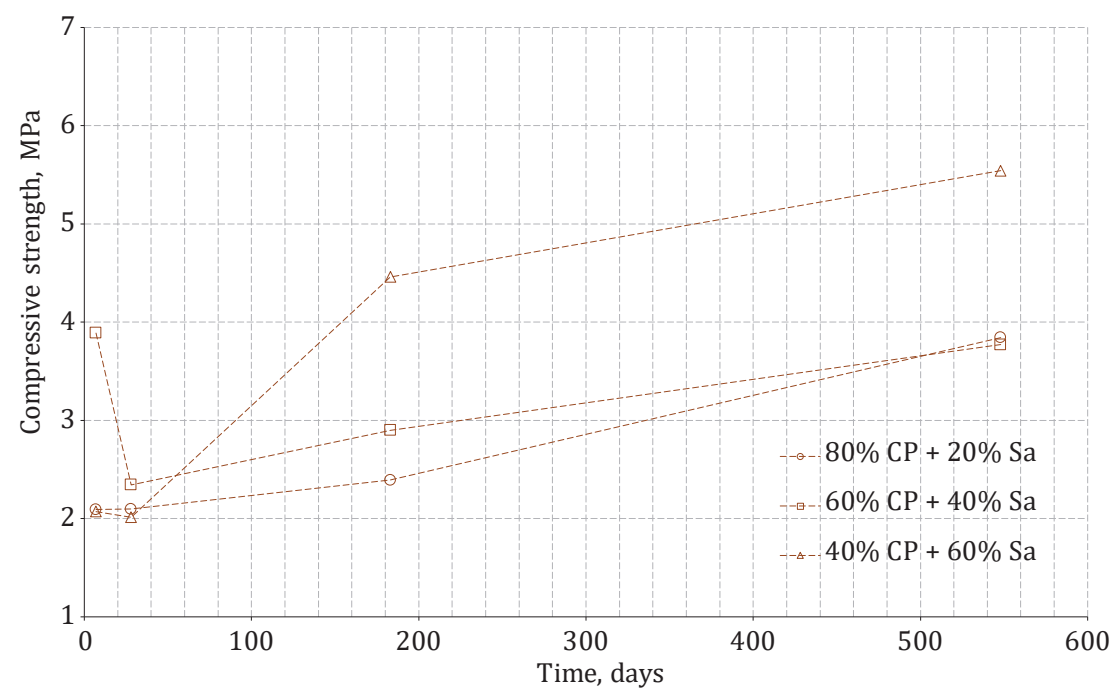

The Effects of Mineral Wool Fly Ash

on Cohesive Soil

Strength Behaviour

Figure 11. Updated compressive strength of samples (70\% Portland cement $+30 \%$ fly ash) after Zakarka et al. (2019)

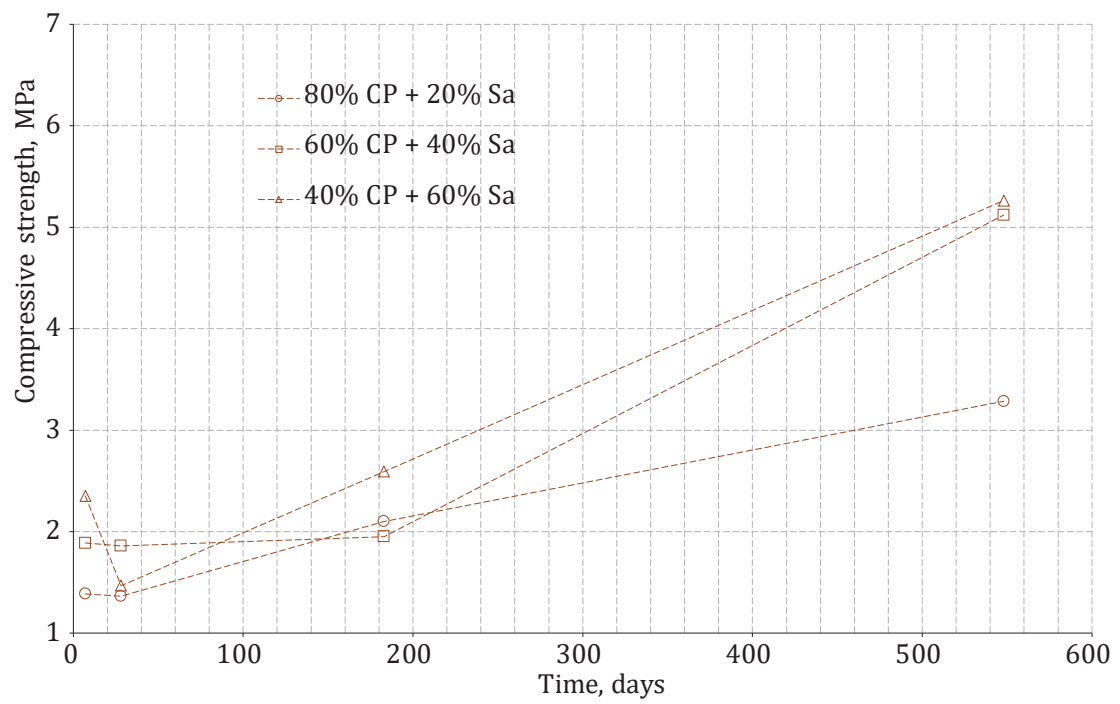

Figure 12. Updated compressive strength of samples (60\% Portland cement $+40 \%$ fly ash) after Zakarka et al. (2019) 


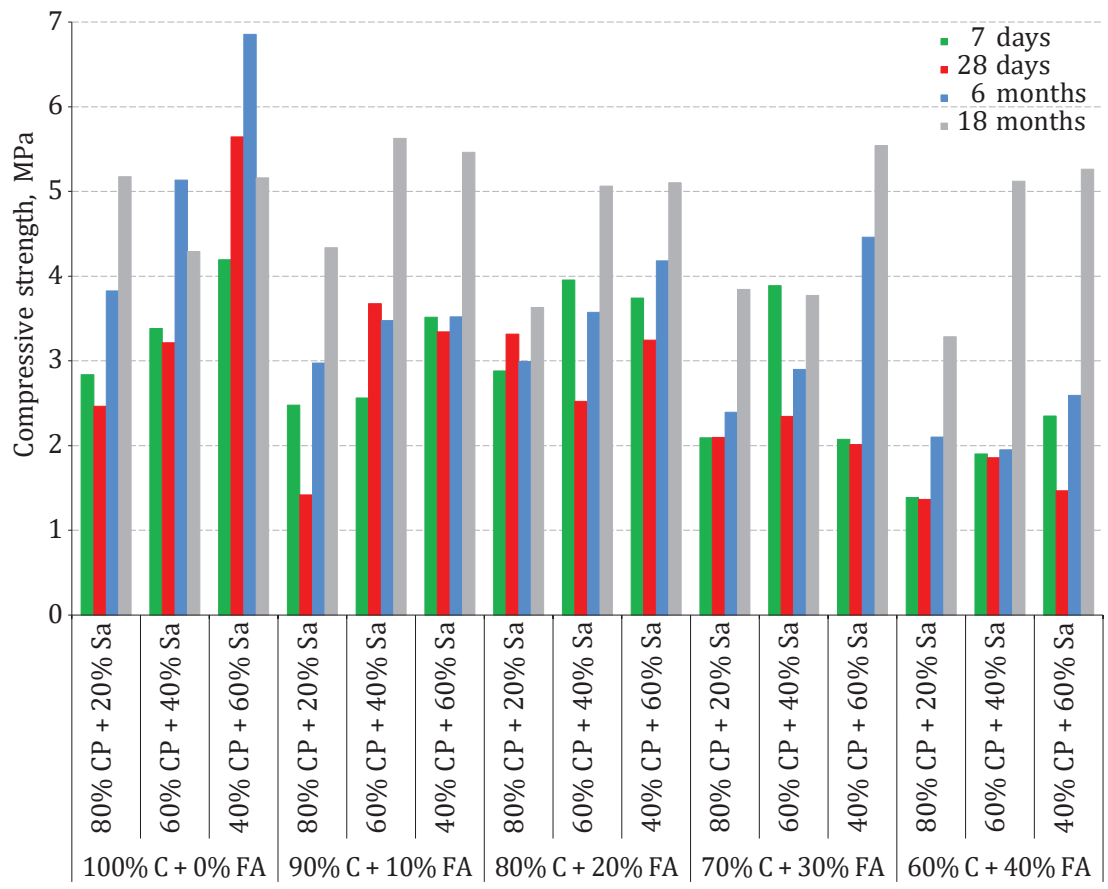

Figure 13. Compressive strength summary graph after Zakarka et al. (2019)

Analysing the summarised results presented in Figure 13, the most predictable compressive strength is observed for samples without fly ash (samples No. 1-3, in Table 3), where the binder is only Portland cement. Also, these samples obtained the highest compressive strength compared to other samples. The change in compressive strength is minimal for samples with 10-30\% fly ash. The highest decrease in compressive strength was obtained after 183 days for samples with $40 \%$ fly ash (samples No. 13-15, in Table 3). Nonetheless, the compressive strength of these samples increased after 548 days and is almost the same as for samples without fly ash.

\section{Conclusions}

The main objective of this study was to update previous research results and evaluate the compressive strength in sandy low plasticity clay when fly ash and Portland cement additives were used. To achieve such an objective, a series of uniaxial compression tests were conducted for samples with different Portland cement, fly ash, sand and clay. In 
total, 15 mixtures were investigated. Obtained results were compared to tests made with a binder of $100 \%$ Portland cement and without fly ash. For this mixture, it was obtained the most predictable compressive strength. Also, for these samples, the highest compressive strength was obtained compared to the other samples mixtures. Change in the compressive strength is minimal for samples with $10-30 \%$ fly ash. The highest decrease of compressive strength was obtained for samples with $40 \%$ fly ash after 183 days.

Nonetheless, the compressive strength of these samples increased after 548 days and is almost the same as for samples without fly ash. After 1.5 years (548 days), each of the investigated samples reached more than $0.5 \mathrm{MPa}$ compressive strength, which is assumed as sufficient strength after soil strengthening. It is rational to limit fly ash quantity admixture in Portland cement by 30\% from the mass of the mixture. Conforming to results obtained after various test periods, the use of fly ash to improve the compression of cohesive soil is promising. In addition, further investigations are needed to create the mixture recipes that depend on soil type and minimum compressive strength requirements.

\section{REFERENCES}

Amran, M., Debbarma, S., \& Ozbakkaloglu, T. (2021). Fly ash-based eco-friendly geopolymer concrete: a critical review of the long-term durability properties. Construction and Building Materials, 270. https://doi.org/10.1016/j.conbuildmat.2020.121857

Baldovino, J. J. A., Izzo, R. L. S., Rose, J. L., \& Domingos, M. D. I. (2021). Strength, durability, and microstructure of geopolymers based on recycled-glass powder waste and dolomitic lime for soil stabilisation. Construction and Building Materials, 271. https://doi.org/10.1016/j.conbuildmat.2020.121874

Behnood, A. (2018). Soil and clay stabilisation with calcium- and non-calcium-based additives: a state-of-the-art review of challenges, approaches and techniques. Transportation Geotechnics, 17, 14-32, https://doi.org/10.1016/j.trgeo.2018.08.002

Bhatt, A., Priyadarshini, S., Mohanakrishnan, A. A., Abri, A., Sattler, M., \& Techapaphawit, S. (2019). Physical, chemical, and geotechnical properties of coal fly ash: a global review. Case Studies in Construction Materials, 11(2019), 1-11. https://doi.org/10.1016/j.cscm.2019.e00263

Binal, A. (2016). The effects of high alkaline fly ash on strength behaviour of a cohesive soil. Advances in Materials Science and Engineering, 2016, 1-11. https://doi.org/10.1155/2016/3048716

Cho, Y. K., Jung, S. H., \& Choi, Y. C. (2019). Effects of chemical composition of fly ash on compressive strength of fly ash cement mortar. Construction and Building Materials, 204(2019), 255-264.

https://doi.org/10.1016/j.conbuildmat.2019.01.208
The Effects of Mineral Wool Fly Ash on Cohesive Soil Strength Behaviour 
THE BALTIC JOURNAL

OF ROAD

AND BRIDGE

ENGINEERING

$2021 / 16(4)$

Chousidis, N., Ioannou, I., Rakanta, E., Koutsodontis, C., \& Batis, G. (2016). Effect of fly ash chemical composition on the reinforcement corrosion, thermal diffusion and strength of blended cement concretes. Construction and Building Materials, 126(2016), 86-97.

https://doi.org/10.1016/j.conbuildmat.2016.09.024

Deepak, M. S., Rohini, S., Harini, B. S., \& Ananthi, G. B. G. (2020). Influence of fly-ash on the engineering characteristics of stabilised clay soil. Materials Today: Proceedings. https://doi.org/10.1016/j.matpr.2020.07.497

Elahi, T. E., Shahriar, A. R., Islam, M. S., Mehzabin, F. S., \& Mumtaz, N. (2020). Suitability of fly ash and cement for fabrication of compressed stabilised earth blocks. Construction and Building Materials, 263(2020), 1-15. https://doi.org/10.1016/j.conbuildmat.2020.120935

Firoozi, A. A., Guney Olgun, C., Firoozi, A. A., \& Baghini, M. S. (2017). Fundamentals of soil stabilisation. Geo-Engineering 8(1), 1-16. https://doi.org/10.1186/s40703-017-0064-9

Fuller, A., Stegmaier, M., Schulz, N., Menke, M., Schellhorn, H., Knödler, F., Maier, J. \& Scheffknecht, G. (2018). Use of wood dust fly ash from an industrial pulverized fuel facility for rendering. Construction and Building Materials, 189(2018), 825-848. https://doi.org/10.1016/j.conbuildmat.2018.09.016

Ghadir, P., \& Ranjbar, N. (2018). Clayey soil stabilisation using geopolymer and Portland cement. Construction and Building Materials, 188, 361-371. https://doi.org/10.1016/j.conbuildmat.2018.07.207

Giergiczny, Z. (2019). Fly ash and slag. Cement and Concrete Research, 124, 1-15. https://doi.org/10.1016/j.cemconres.2019.105826

Graytee, A., Sanjayan, J. G., \& Nazari, A. (2018). Development of a high strength fly ash-based geopolymer in short time by using microwave curing., Ceramics International, 44(7), 8216-8222.

https://doi.org/10.1016/j.ceramint.2018.02.001

$\mathrm{Gu}, \quad$ K., \& Chen, B. (2020). Loess stabilisation using cement, waste phosphogypsum, fly ash and quicklime for self-compacting rammed earth construction. Construction and Building Materials, 231, 1-9. https://doi.org/10.1016/j.conbuildmat.2019.117195

Guo, X., Shi, H., \& Wei, X. (2017). Pore properties, inner chemical environment, and microstructure of nano-modified CFA-WBP (class C fly ash-waste brick powder) based geopolymers. Cement and Concrete Composites, 79, 53-61. https://doi.org/10.1016/j.cemconcomp.2017.01.007

Jalal, F. E., Yongfu Xu, Y., Jamhiri B., \& Memon, S. A. (2020). On the recent trends in expansive soil stabilisation using calcium-based stabiliser materials (CSMS): a comprehensive review. Advances in Materials Science and Engineering, 2020, 1-23. https://doi.org/10.1155/2020/1510969

Jia, Z., Fu, L., \& Wang, L. (2020). Magnesium salt influenced strength behavior of lime-fly ash stabilised fine grained soil. Materials Science, 26(3), 373-378. https://doi.org/10.5755/j01.ms.26.3.21825

Kang, S., Lloyd, Z., Kim, T., \& Ley, M. T. (2020). Predicting the compressive strength of fly ash concrete with the Particle Model. Cement and Concrete Research, 137. https://doi.org/10.1016/j.cemconres.2020.106218 
Karim, R., Hossain, M., Elahi, M., \& Zain, M. F. M. (2020). Effects of source materials, fineness and curing methods on the strength development of alkali-activated binder, Journal of Building Engineering, 29. https://doi.org/10.1016/j.jobe.2019.101147

Khajeh, A., Chenari, R. J., \& Payan, M. (2020). A simple review of cemented non-conventional materials: soil composites. Geotechnical and Geological Engineering, 38(2), 1019-1040. https://doi.org/10.1007/s10706-019-01090-x

Kim, A. G., Kazonich, G., \& Dahlberg, M. (2003). Relative solubility of cations in class F fly ash. Environmental Science and Technology, 37(19), 4507-4511. https://doi.org/10.1021/es0263691

Li, Y., Jia, S., \& Liu, J. (2018). The solidification mechanism of cement and fly ash towards contaminated soil. Chemical Engineering Transactions, 67, 571-576. https://doi.org/10.3303/CET1867096

Liang, S., Chen, J., Guo, M., Feng, D., Liu, L., \& Qi, T. (2020). Utilisation of pretreated municipal solid waste incineration fly ash for cement-stabilised soil. Waste Management, 105, 425-432.

https://doi.org/10.1016/j.wasman.2020.02.017

Lithuanian Geology Survey (2019). Engineering Geological and Geotechnical Soil Investigations Classification. Ministry of Environment of the Republic of Lithuania (in Lithuanian)

LST CEN ISO/TS 17892-4:2017 Geotechnical investigation and testing - Laboratory testing of soil - Part 4: Determination of particle size distribution (in Lithuanian)

LST CEN ISO/TS 17892-12:2018 Geotechnical investigation and testing - Laboratory testing of soil - Part 12: Determination of liquid and plastic limits (in Lithuanian)

LST EN 197-1:2011/P:2013 Cement - Part 1: Composition, specifications and conformity criteria for common cements (in Lithuanian)

Luo, T., Ma, S., Zheng, S., Liu, C., Han, D., \& Wang, X. (2018). Mullite-based ceramic tiles produced solely from high-alumina fly ash: preparation and sintering mechanism. Journal of Alloys and Compounds, 218(732), 828-837. https://doi.org/10.1016/j.jallcom.2017.09.179

Mackevičius, R., Sližytė, D., Zhilkina, T., \& Turchin, V. (2019). Investigation of influence of additives on properties of multi-molecular organic solutions used for permeation grouting. Proceedings of 13th International Conference Modern Building Materials, Structures and Techniques, 16-17 May 2019, Vilnius, Lithuania, 425-430.

Mahedi, M., Cetin, B., \& White, D. J. (2018) Performance evaluation of cement and slag stabilised expansive soils. Transportation Research Record, 2672(52), 164-173. https://doi.org/10.1177/0361198118757439

Mirković, K., Tošić, N., \& Mladenović, G. (2019). Effect of different types of fly ash on properties of asphalt mixtures. Advances in Civil Engineering, 2019, 1-11. https://doi.org/10.1155/2019/8107264

Moon, G. D., Oh, S., \& Choi, Y. C. (2016). Effects of the physicochemical properties of fly ash on the compressive strength of high-volume fly ash mortar. Construction and Building Materials, 124, 1072-1080.

https://doi.org/10.1016/j.conbuildmat.2016.08.148
Mindaugas Zakarka,

The Effects of Mineral Wool Fly Ash

on Cohesive Soil

Strength Behaviour 
THE BALTIC JOURNAL

OF ROAD

AND BRIDGE

ENGINEERING

$2021 / 16(4)$

Nath, B. D., Molla, K. A., \& Sarkar, G. (2017). Study on strength behavior of organic soil stabilised with fly ash. International Scholarly Research Notices, 2017, 1-6. https://doi.org/10.1155/2017/5786541

Phummiphan, I., Horpibulsuk, S., Sukmak, P., Chinkulkijniwat, A., Arulrajah, A., \& Shen, S. L. (2016). Stabilisation of marginal lateritic soil using high calcium fly ash-based geopolymer. Road Materials and Pavement Design, 17(4), 877-891. https://doi.org/10.1080/14680629.2015.1132632

Pundinaitė-Barsteigienè, M., Bačinskas, D., Spudulis, E., \& Rumšys, D. (2017). MSWI bottom ash utilisation in concrete mixes. Science - Future of Lithuania, 9(5), 524-530. https://doi.org/10.3846/mla.2017.1081

Riekstins, A., Haritonovs, V., \& Straupe, V. (2020). Life Cycle Cost Analysis and Life Cycle Assessment for road pavement materials and reconstruction technologies. The Baltic Journal of Road and Bridge Engineering, 15(5), 118-135. https://doi.org/10.7250/bjrbe.2020-15.510

Sharman, A. K., \& Sivapullaiah, P. V. (2016). Ground granulated blast furnace slag amended fly ash as an expansive soil stabiliser. Soils and Foundations, 56(2), 205-212. https://doi.org/10.1016/j.sandf.2016.02.004

Simatupang, M., Mangalla, L. K., Edwin, R. S., Putra A. A., Azikin, M. T., Aswad, N. H., \& Mustika, W. (2020). The mechanical properties of fly-ash-stabilised sands. Geosciences, 10(4), 1-19. https://doi.org/10.3390/geosciences10040132

State Enterprise Lithuanian Road Administration (2012). MN GPSR 12 Gruntu pagerinimo ir sustiprinimo rišikliais metodiniai nurodymai. 25 p. (in Lithuanian)

Stonys, R., Kuznetsov, D., Krasnikovs, A., Škamat, J., Baltakys, K., Antonovič, V., \& Černašejus, O. (2016). Reuse of ultrafine mineral wool production waste in the manufacture of refractory concrete. Journal of Environmental Management, 176, 146-156. https://doi.org/10.1016/j.jenvman.2016.03.045

Trivedi, J. S., Nair, S., \& Iyyunni, C. (2013). Optimum utilisation of fly ash for stabilisation of sub-grade soil using genetic algorithm. Procedia Engineering, 51(2013), 250-258. https://doi.org/10.1016/j.proeng.2013.01.034

Vaitkus, A., Gražulytè, J., Vorobjovas, V., Šernas, O., \& Kleizienė, R. (2018). Potential of MSWI bottom ash to be used as aggregate in road building materials. Baltic Journal of Road and Bridge Engineering, 13(1), 77-86. https://doi.org/10.3846/bjrbe.2018.401

Wong, L. S. (2015). Formulation of an optimal mix design of stabilised peat columns with fly ash as a pozzolan. Arabian Journal for Science and Engineering, 40, 1015-1025. https://doi.org/10.1007/s13369-015-1576-2

Woszuk, A., Bandura, L., \& Franus, W. (2019). Fly ash as low cost and environmentally friendly filler and its effect on the properties of mix asphalt, Journal of Cleaner Production, 235, 493-502. https://doi.org/10.1016/j.jclepro.2019.06.353

Yliniemi, J., Walkley, B., Provis, J. L., Kinnunen, P., \& Illikainen, M. (2020). Nanostructural evolution of alkali-activated mineral wools. Cement and Concrete Composites, 106(2020).

https://doi.org/10.1016/j.cemconcomp.2019.103472 
Yoobanpot, N., Jamsawang, P., \& Horpibulsuk., S. (2017). Strength behavior and microstructural characteristics of soft clay stabilised with cement kiln dust and fly ash residue. Applied Clay Science, 141, 146-156. https://doi.org/10.1016/j.clay.2017.02.028

Zakarka, M., Mackevičius, R., Skuodis, Š., Sližytė, D., \& Kudžma, A. (2019). Stabilisation of clay powder with mineral wool fly ash. Engineering Structures and Technologies, 11(4), 106-113. https://doi.org/10.3846/est.2019.12021

Zarins, A. (2020). Case study on the effect of recycled asphalt layer parameters on the bearing capacity of the pavement. The Baltic Journal of Road and Bridge Engineering, 15(5), 45-58. https://doi.org/10.7250/bjrbe.2020-15.506

Župerkienė, E., Šimanskienè, L., Labanauskaitè, D., Melnikova, J., \& Davidavičienè, V. (2021). The COVID-19 pandemic and resilience of SMEs in Lithuania. Entrepreneurship and Sustainability Issues, 8(3), 53-65.

http://doi.org/10.9770/jesi.2021.8.3(4)
The Effects of Mineral Wool Fly Ash on Cohesive Soil Strength Behaviour 